\title{
Identifying hot and cool spots in the city centre based on bicycle measurements: the case of Olomouc, Czech Republic
}

\author{
Michal Lehnert ${ }^{A *}$, Josef Kubeček ${ }^{A}$, Jan Geletič ${ }^{B}$, Martin Jurek ${ }^{A}$, Jindřich Frajer ${ }^{A}$ \\ Received: December 03, 2018 | Revised: December 25, 2018 | Accepted: December 27, 2018
}

DOI: $10.5937 / g p 22-19750$

\begin{abstract}
In this study we focus on a detailed analysis of air temperature in the city centre of Olomouc, using a bicycle for mobile measurements. We studied the spatial pattern of air temperature, analysed temperature differences between local climate zones (LCZs) and identified hot spots and cool spots in the city centre. The results point to a significant influence of microclimate and local climate on the field of temperature. In the daytime, hotspots occurred namely in LCZ 8 and E and in the well irradiated spaces within LCZ 2. Larger areas of scattered trees (LCZ B) in combination with watercourses created cool spots with a cooling potential for their surroundings. During night time, the warmest spots were detected mostly in LCZ 2 and the coolest spots in areas with low plants (LCZ D).
\end{abstract}

Keywords: urban climate; local climate zones; mobile measurement

\section{Introduction}

One of the most demanding challenges of sustainable urban planning today is the changing climate. The IPCC (2014) strongly suggests that municipalities prepare adaptation measures to avoid serious impacts of climate change. Many cities concerned about the health of their population already consider controlling the local climate and microclimate in the urban environment as a crucial tool for reducing heat stress and facilitating a better living environment in the city (Mutani \& Fiermonte, 2016).

Recording air temperature in urban areas using mobile measurements has become an established method of urban climate research (Stewart, 2011). Traverses have been carried out using various means of transport, such as bicycle, car, bus or tram, (e.g. Quitt, 1956; Melhuish \& Pedder, 1998; Buttstädt et al., 2011) or on foot (Tsin et al.,
2016) and usually complement fixed site measurements (Dobrovolný et al., 2012; Lelovics et al., 2014). Currently, the main objectives of mobile air temperature measurements are 1) to analyse physical properties of the environment influencing the spatial pattern of air temperature in urban areas (e.g. Dobrovolný \& Krahula, 2015; Rajkovich \& Larsen, 2016; Lehnert et al., 2018), 2) to provide input data for extrapolation or interpolation methods resulting in urban temperature maps (e.g. Dobrovolný \& Krahula, 2015; Alexander \& Mills, 2014; Liu et al. 2017) and 3) to validate outputs of local climate and microclimate simulations (e.g. Tsin et al., 2016; Queck and Goldberg, 2018).

Values of main physical properties of the environment influencing urban temperature field on a local scale were recently grouped into the concept of Local Climate

A Department of Geography, Faculty of Science, Palacký University in Olomouc, 17. listopadu 12, 77146 Olomouc, Czech Republic; m.lehnert@upol.cz; j.kubecek@gmail.com; jindrich.frajer@upol.cz; martin.jurek@upol.cz

B Institute of Computer Science of the Czech Academy of Sciences, 18207 Prague 8, Czech Republic \& Global Change Research Institute of the Czech Academy of Sciences, 60300 Brno, Czech Republic; email: geletic@cs.cas.cz

* Corresponding author: Michal Lehnert; e-mail: m.lehnert@upol.cz; tel. +420 585634509 
Zones (LCZs). LCZs consist of areas of uniform surface cover structure, material, and human activity; they may cover areas ranging from hundreds of metres to several kilometres on the horizontal scale (Stewart \& Oke, 2012). Several studies dealing with relation of air temperature and LCZs using various research methods of LCZs were published soon after the initial definition of LCZs. For instance, Fenner et al. (2014), Müller et al. (2014), Lehnert et al. (2015) or Gál et al. (2016) analysed thermal differences of LCZs based on dense monitoring networks. An advantage of this approach lies in data availability for a longer period, while its disadvantage is a limited spatial representativeness. Geletič et al. (2016a), Wang et al. (2018) or Cai et al. (2018) used land surface temperature (LST) to analyse LCZ differences. The advantage of this approach is the spatial extent of the data; however, disadvantages are limited temporal sample and existing differences between air temperature and LST. Other authors used mobile air temperature measurements (traverses) to analyse differences between LCZs (Stewart et al., 2014; Alexander \& Mills, 2014; Leconte et al., 2015; Lelovics et al., 2014 or Lehnert et al., 2018). The advantage of this method lies in its spatial representativeness and the main disadvantages are limited temporal sam- pling and limited access by car to certain areas typical for particular LCZs (e.g. parks, narrow historical streets etc.). This limitation is substantially reduced when a bicycle is used instead of a car. Most of these studies proved substantial or significant thermal differences between different LCZs (inter-zonal variability) during daytime. Nevertheless, a substantial temperature variation within LCZs (intra-zonal variability) was also detected (Fenner et al., 2014; Lehnert et al., 2015, 2018; Leconte et al., 2015; Skarbit et al., 2017). Especially during daytime, when the influence of direct solar radiation and turbulence contributes to the development of a complex field of air temperature, thermal relevance of LCZs has not been convincingly proved so far and seems disputable (e.g. Quanz et al., 2018).

In this study we focus on a detailed air temperature analysis in the city centre of Olomouc using mobile bicycle measurements with the following objectives: 1) to obtain detailed information about air temperature field in areas not accessible by car; 2) to analyse the differences between LCZs for both daytime and night time and different seasons; and 3) to identify areas vulnerable to heat stress temperatures and areas that are cooling the city centre.

\section{Study area}

The city of Olomouc is situated in the eastern part of the Czech Republic. Olomouc has a land registry area of $103 \mathrm{~km}^{2}$ and 100,500 inhabitants (the sixth largest city in the country; CZSO, 2018). Urban structure of the city with a complex set of land-cover and building types represents a typical central European mid-size city. Olomouc is located in a flat basin. The field measurements were carried out in the city centre where elevation differences are low (up to $20 \mathrm{~m}$ ). The city centre consists of midrise historical buildings with courtyards and narrow streets. Open areas are represented by the city squares covered by impervious surfaces (granite setts) with few or no vegetation. The historical city centre is surrounded by city parks and beyond these parks, the urban structure consists of mixed urban forms; with open midrise residence buildings (blocks of flats) in the north of the study area and former industrial zones transformed to commercial areas in the south (see Figure 1). The average annual temperature in Olomouc is $8.9^{\circ} \mathrm{C}$, the warmest month is July $\left(19.1^{\circ} \mathrm{C}\right)$ and the coldest January $\left(-2.2^{\circ} \mathrm{C}\right)$. The average annual rainfall is $546.7 \mathrm{~mm}$ (1961-2010 reference period). The corresponding climate zone according to the Köppen classification is Cfb (Tolasz et al., 2007).

\section{Data and methods}

\section{Mobile measurements}

The mobile measurement campaign using a bicycle was carried out from July 2016 until February 2017, thus covering the summer, autumn and winter season. The route of the mobile measurement was designed: 1) to cover the central parts of the city, including narrow streets and parks non-accessible by car, and 2) to include the areas of most LCZ types located in the central part of the city. The route was $9 \mathrm{~km}$ long, beginning and ending at the same location (Upper Square; see Figure 1). On average it took less than 40 minutes to complete the route (Table
1). The measurements were performed twice a day; daytime measurements were carried out during apparent noon and night-time measurements two hours after sunset. The measurements were performed in days with no forecasted precipitation. Meteorological conditions during the measurement campaigns are described in Table 1. After preliminary assessment of the data quality (excluding measurements with technical problems, errors, and with substantial change of weather conditions during the measurement), 16 days of the campaign were suitable for further analysis (Table 1). 
A temperature sensor (FHA646E; accuracy $0.1^{\circ} \mathrm{C}$ ) was mounted in the radiation shield at the height of $1.8 \mathrm{~m}$ at the front side of the bicycle (Figure 1). This placement minimalizes the influence of heat emitted from the body of the rider. The sensor was connected to ALMEMO 2690-8 data logger which recorded temperature in $5 \mathrm{~s}$ intervals. At the same time, the datalogger was synchronized with a GPS device recording the position of the measurement. The riding speed was maintained in the range of 10 to $15 \mathrm{~km} \cdot \mathrm{h}^{-1}$ during the measurement and any data measured at a speed lower than $5 \mathrm{~km} \cdot \mathrm{h}^{-1}$ were removed from the dataset.

For further analysis, data obtained from the mobile measurements were corrected on temperature change during the campaign using the method of Dobrovolný and Krahula (2015). The correction was based on urban stations located in victinity of the route (for more information see Lehnert et al, 2015 and 2018). Finally, the data were smoothed with a 5-point average filter to suppress the noise and thermal inertia of the sensor; i.e. the temperature at a particular point along the route was calculated from the temperature recorded at that point and from four following route points (with the records taken in $5 \mathrm{~s}$ steps).

\section{Local climate zones}

The map of local climate zones (LCZ) used for the analysis in this study was prepared by Geletič and Lehnert (2016). The method used for LCZ delineation is based on measurable physical properties of the environment and a clearly-defined decision-making algorithm. This algorithm includes the following basic physical parameters defined by Stewart and Oke (2012): building surface fraction (BSF), pervious surface fraction (PSF), impervious surface fraction (ISF) and height of roughness elements (HRE). These were supplemented by the number of buildings (NoB). For the classification process, the study area was divided into a regular grid of 100×100-m cells and each cell was assigned to a certain LCZ based on the values of the defined physical parameters. In the following step, LCZ areas were delineated using a majority filter (for details see Geletič \& Lehnert, 2016). Using the resulting LCZ map as a background for the analysis (Figure 1), the route of the mobile measurement passed through eight different zones (LCZ 2 - compact midrise, LCZ 5 - open midrise, LCZ 6 - open low-rise, LCZ 8 - large low-rise, LCZ 9 - sparsely built, LCZ B - scattered trees, LCZ D - low plants, LCZ E - bare rock or paved).
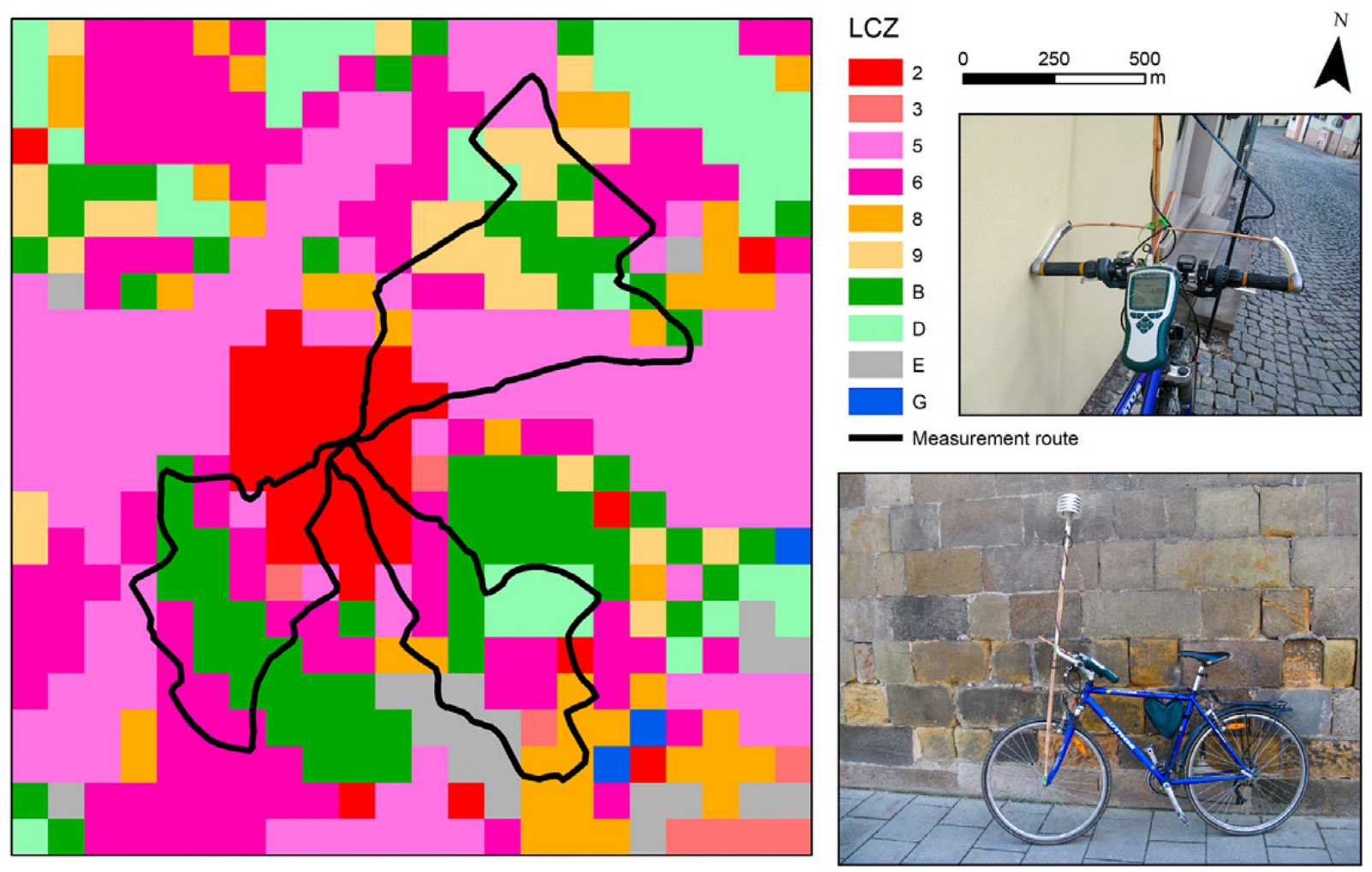

Figure 1. Measurement route across delineated LCZs of the city centre of Olomouc and the bicycle mounted with measurement apparatus.

Source: edited by the authors. 


\section{Data analyses}

In the first step, temperature differences between LCZs were analysed based on the differences of the mean temperatures measured in the particular zones (e.g. mean temperature of all measurement points assigned to a given LCZ class) from the mean temperature of the whole measurement. For further analyses of the LCZs, inter-zonal temperature differences were studied using the Kruskal-Wallis one-way anal- ysis of variance. When the Kruskal-Wallis ANOVA Ftest $(p<0.001)$ indicated statistically significant differences in mean air temperatures for an individual LCZ, the Tukey HSD test $(p>0.05)$ was employed to reveal which LCZs differed significantly in their mean air temperatures. The analysis was performed for all 32 measurements (16 daytime and 16 night-time) and evaluated separately for daytime and night-time measurements.

\section{Results}

\section{Mobile measurements of temperature}

The range of temperatures during the noon measurements in the city centre of Olomouc was 0.6 to $2.2^{\circ} \mathrm{C}$ (Table 1). There was no significant influence of seasonality and weather on the temperature variability. The warmest localities during the noon hours were mostly paved surfaces well irradiated by the sun (namely areas adjacent to the shopping mall), including the situation with snow cover (measurement of 7 January 2017). The temperature field was influenced by the orienta- tion of the street grid; relatively higher temperatures were detected in the SE-NW oriented streets, which are well irradiated in the morning hours and accumulate a significant thermal load by the early afternoon. Relatively lower temperatures were detected during the noon hours namely in locations with a higher degree of shading, provided by full-grown trees in the parks and dense structure of midrise buildings in the city centre. The lowest temperatures were regularly detected in the lower-lying locality of the park with a

Table 1. Basic characteristics of the mobile measurements.

\begin{tabular}{|c|c|c|c|c|c|c|c|c|c|c|}
\hline \multicolumn{3}{|l|}{ Date } & 08/08 & $23 / 08$ & $25 / 08$ & $26 / 08$ & $27 / 08$ & $30 / 08$ & 07/09 & 08/09 \\
\hline \multirow{6}{*}{ 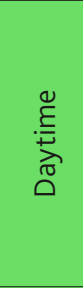 } & Mean temperature & {$\left[{ }^{\circ} \mathrm{C}\right]$} & 26.9 & 23.7 & 25.0 & 26.2 & 27.5 & 24.3 & 23.3 & 26.0 \\
\hline & Range & {$\left[\Delta^{\circ} \mathrm{C}\right]$} & 1.4 & 2.0 & 1.9 & 1.6 & 2.1 & 2.1 & 2.2 & 2.1 \\
\hline & Standard deviation & {$\left[\Delta^{\circ} \mathrm{C}\right]$} & 0.3 & 0.4 & 0.4 & 0.4 & 0.5 & 0.4 & 0.5 & 0.4 \\
\hline & Cloudiness & [tenths] & 1 & 7 & 1 & 0 & 0 & 4 & 3 & 3 \\
\hline & Mean wind speed & {$\left[\mathrm{m} \cdot \mathrm{s}^{-1}\right]$} & 4.0 & 2.0 & 2.1 & 4.0 & 3.7 & 2.5 & 4.3 & 3.3 \\
\hline & Wind direction & [dir.] & $S$ & $\mathrm{NE}$ & $\mathrm{NE}$ & SE & $S$ & NW & $E$ & S, SE \\
\hline \multirow{6}{*}{ 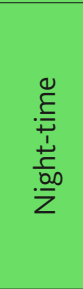 } & Mean temperature & {$\left[{ }^{\circ} \mathrm{C}\right]$} & 21.2 & 19.0 & 19.3. & 18.8 & 21.8 & 17.4 & 18.9 & 20.1 \\
\hline & Range & {$\left[\Delta^{\circ} \mathrm{C}\right]$} & 2.5 & 2.5 & 3.5 & 4.1 & 2.4 & 1.5 & 2.5 & 3.3 \\
\hline & Standard deviation & {$\left[\Delta^{\circ} \mathrm{C}\right]$} & 0.6 & 0.6 & 0.8 & 1.0 & 0.6 & 0.4 & 0.7 & 0.9 \\
\hline & Cloudiness & [tenths] & 1 & 5 & 1 & 0 & 0 & 2 & 0 & 0 \\
\hline & Mean wind speed & {$\left[\mathrm{m} \cdot \mathrm{s}^{-1}\right]$} & 2.7 & 0.6 & 1.7 & 2.6 & 2.5 & 1.3 & 2.1 & 3.0 \\
\hline & Wind direction & [dir.] & $E$ & SW & $\mathrm{N}, \mathrm{E}$ & $\mathrm{NE}, \mathrm{SE}$ & $\mathrm{NE}$ & NW & $\mathrm{N}, \mathrm{E}$ & $\mathrm{NE}$ \\
\hline \multicolumn{3}{|l|}{ Date } & $14 / 09$ & $15 / 09$ & $22 / 09$ & $28 / 09$ & $31 / 10$ & $29 / 11$ & $05 / 12$ & $07 / 01$ \\
\hline \multirow{6}{*}{ 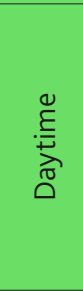 } & Mean temperature & {$\left[{ }^{\circ} \mathrm{C}\right]$} & 27.0 & 24.4 & 16.8 & 17.8 & 8.2 & 0.4 & -2.5 & -11.5 \\
\hline & Range & {$\left[\Delta^{\circ} \mathrm{C}\right]$} & 1.2 & 1.9 & 1.9 & 1.3 & 0.6 & 0.7 & 1.5 & 2.1 \\
\hline & Standard deviation & {$\left[\Delta^{\circ} \mathrm{C}\right]$} & 0.2 & 0.4 & 0.4 & 0.3 & 0.2 & 0.2 & 0.4 & 0.5 \\
\hline & Cloudiness & [tenths] & 3 & 3 & 6 & 8 & 5 & 7 & 4 & 1 \\
\hline & Mean wind speed & {$\left[\mathrm{m} \cdot \mathrm{s}^{-1}\right]$} & 3.4 & 2.9 & 2.1 & 3.8 & 2.4 & 3.2 & 1.8 & 1.8 \\
\hline & Wind direction & [dir.] & $\mathrm{N}$ & SE & $\mathrm{NE}$ & $E$ & NW & W & $\mathrm{NE}$ & $\mathrm{NE}$ \\
\hline \multirow{6}{*}{ 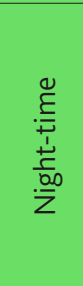 } & Mean temperature & {$\left[{ }^{\circ} \mathrm{C}\right]$} & 21.6 & 21.1 & 11.2 & 18.9 & 5.5 & -1.2 & -0.7 & -11.6 \\
\hline & Range & {$\left[\Delta^{\circ} \mathrm{C}\right]$} & 1.9 & 1.4 & 2.5 & 1.9 & 1.7 & 1.3 & 1.1 & 0.8 \\
\hline & Standard deviation & {$\left[\Delta^{\circ} \mathrm{C}\right]$} & 0.5 & 0.4 & 0.8 & 0.4 & 0.4 & 0.4 & 0.3 & 0.2 \\
\hline & Cloudiness & [tenths] & 1 & 5 & 3 & 8 & 10 & 2 & 10 & 8 \\
\hline & Mean wind speed & {$\left[\mathrm{m} \cdot \mathrm{s}^{-1}\right]$} & 1.4 & 3.3 & 3.2 & 1.9 & 1.7 & 0.5 & 1.1 & 1.8 \\
\hline & Wind direction & [dir.] & $N$ & $E$ & $\mathrm{NE}$ & $\mathrm{NE}$ & $\mathrm{N}, \mathrm{NW}$ & $\mathrm{N}$ & $S$ & $S$ \\
\hline
\end{tabular}

Source: Czech Hydrometeorological institute and own measurement 

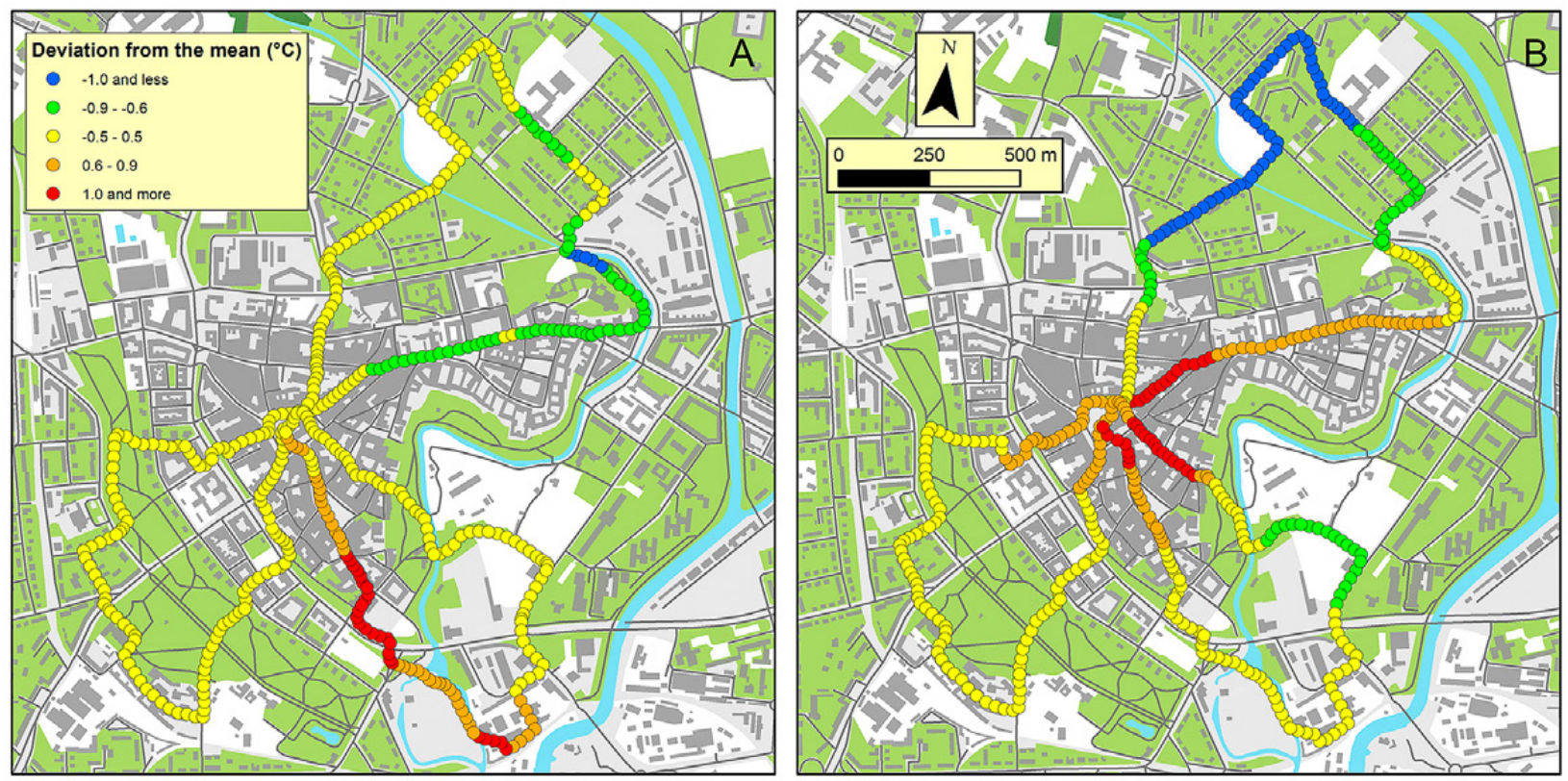

Figure 2. Deviation from the mean temperature of the measurement:

(A) 25 September at daytime; (B) 7 September at night-time

watercourse to the northeast of the compact built-up area of the city centre, which is well documented e.g. by the measurements of 25 September 2016 (Figure 2).

In the evening hours the variability of air temperature in the city centre of Olomouc was larger than during the noon hours, with the temperature range varying between 0.8 and $4.1^{\circ} \mathrm{C}$ (Table 1). The temperature variability during the night-time measurements was the highest in the summer period and the lowest in the winter situations with snow cover. Standard deviation of the measured temperatures was higher during days with low cloudiness combined with a lower wind speed (Table 1). The highest temperatures were detected during the evening hours in the historical city centre, where the urban heat island was clearly developed in most of the cases. The highest temperatures were detected in the relatively narrow streets without larger green areas in their vicinity. This is well documented e.g. by the evening measurements from 7 September 2016 (Figure 2). The shape of the urban heat island was largely influenced by the predominant wind direction, considering the adjacent cooler localities of the city centre (park with a watercourse). Cooler localities were bound to larger green areas with a lack of paved surfaces.

\section{Temperature differences of local climate zones}

The temperature differences between LCZs (their inter-zonal variability) in the city centre of Olomouc during the noon hours were most pronounced in the days with low cloudiness and low wind speeds. The highest temperatures were regularly detected during the noon measurements in LCZ E (bare rock or paved) or LCZ 8 (large low-rise), see Figure 3. The temperature differences of LCZ E or LCZ 8 compared to the other LCZs during the days with low cloudiness were in most cases statistically significant (Table 2). For LCZ 2 (compact midrise) the temperatures were only slightly higher than average at noon and for LCZ 5 (open midrise) and LCZ 6 (open low-rise) slightly lower than average. Lower than average temperatures were detected in most cases for LCZ 9 (sparsely built), LCZ B (scattered trees) and LCZ D (low plants). It is worth noting that the differences between LCZs 9, B and $\mathrm{D}$ and the other LCZs were pronounced namely in the vegetation season (the measurements in $\mathrm{Au}-$ gust and September) while the measurements during October to January in these LCZs detected temperature means much closer to the mean temperature of all LCZs (Figure 3).

The night-time temperature differences between LCZs were generally higher than during the noon hours and they were most pronounced again in the days with low cloudiness and low wind speeds. The seasonality of temperature differences was also apparent, with the highest differences in the summer period and the lowest differences in the winter (Figure 3).

The highest temperatures were detected in LCZ 2 (compact midrise) in almost all cases (except for 14 September) and the temperature differences between LCZ 2 and the other LCZs were statistically significant in $93 \%$ of all cases across the whole measurement campaign (Table 2). Apart from $\mathrm{LCZ}_{2}$, above-average temperatures were repeatedly detected only for LCZ 5 (open midrise). The lowest temperatures were in most cases detected in LCZ 9 (sparsely built), represented 

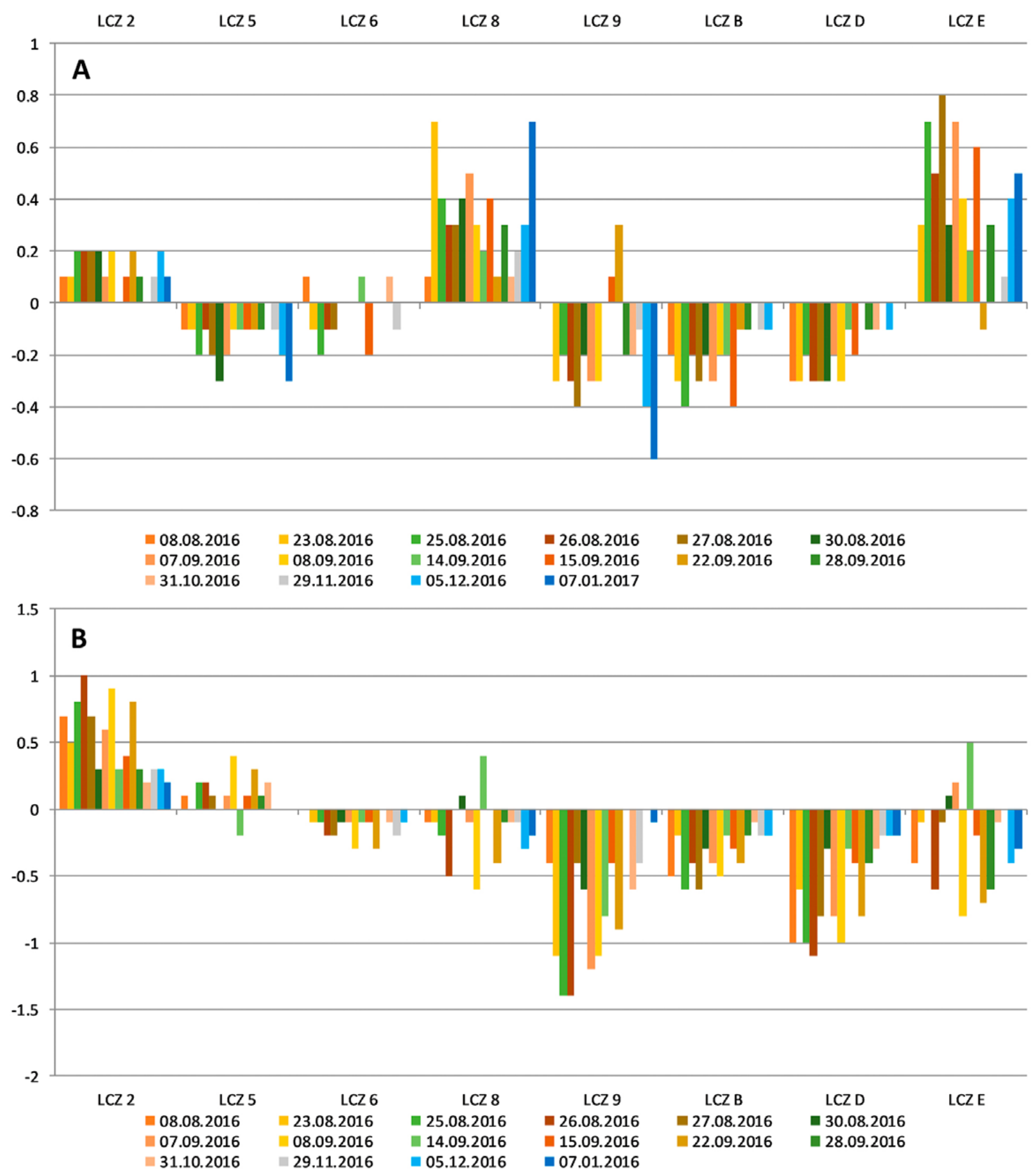

Figure 3. Deviations from mean temperature for individual LCZs during

(A) daytime measurements; (B) night-time measurements.

by a rather small area close to two watercourses. Statistically significantly lower temperatures in comparison to most LCZs were repeatedly detected in LCZ D (low plants) and LCZ B (scattered trees). Similar to the daytime measurements, the significantly lower temperatures in LCZ D and B were detected during the vegetation season (August and September measurements), while in the period from October to January the mean temperatures of those LCZs were much closer to the mean temperature of all LCZs.
Apart from the temperature differences between LCZs it is necessary to explain the temperature variability within individual LCZs (intra-zonal variability) which was primarily influenced by the varying area and uneven distribution of the LCZs across the study area. The variance of temperatures in individual LCZs was largely influenced by wind speed and prevailing wind direction in relation to the position of the neighbouring LCZs.

The smallest variability of temperature was characteristic for LCZ 9 (sparsely built), represented by only a 
Table 2. Share (in \%) of statistical significance of the median difference between all combinations of LCZs based on analyses of Kruskal-Wallis ANOVA for daytime and night-time measurements.

\begin{tabular}{|c|c|c|c|c|c|c|c|c|c|c|c|c|c|c|c|c|c|}
\hline \multicolumn{1}{|c|}{ Daytime measurements } & \multicolumn{1}{|c|}{ Mean } & \multicolumn{4}{|c|}{ Night-time measurements } & Mean \\
\hline 2 & 88 & 56 & 31 & 75 & 88 & 69 & 44 & 64 & 2 & 88 & 100 & 94 & 94 & 100 & 100 & 75 & 93 \\
\hline 88 & 5 & 38 & 94 & 0 & 13 & 6 & 81 & 46 & 88 & 5 & 13 & 50 & 75 & 75 & 88 & 50 & 63 \\
\hline 56 & 38 & 6 & 69 & 38 & 44 & 38 & 63 & 49 & 100 & 13 & 6 & 13 & 63 & 13 & 63 & 31 & 42 \\
\hline 31 & 94 & 69 & 8 & 75 & 94 & 94 & 0 & 65 & 94 & 50 & 13 & 8 & 56 & 38 & 50 & 0 & 43 \\
\hline 75 & 0 & 38 & 75 & 9 & 19 & 31 & 81 & 46 & 94 & 75 & 63 & 56 & 9 & 44 & 6 & 56 & 56 \\
\hline 88 & 13 & 44 & 94 & 19 & B & 6 & 81 & 49 & 100 & 75 & 13 & 38 & 44 & B & 25 & 44 & 48 \\
\hline 69 & 6 & 38 & 94 & 31 & 6 & D & 94 & 48 & 100 & 88 & 63 & 50 & 6 & 25 & D & 25 & 51 \\
\hline 44 & 81 & 63 & 0 & 81 & 81 & 94 & E & 63 & 75 & 50 & 31 & 0 & 56 & 44 & 25 & E & 40 \\
\hline
\end{tabular}

small homogenous area in the north of the study area. LCZ E (bare rock or paved) also showed low variability of temperature; this type was represented by one locality in the south of the study area. On the contrary, the highest values of standard deviation were detected at LCZ 5 (open midrise), where the large temperature variability during daytime measurements is attributed to varying street orientation and exposure to direct solar radiation (Figure 4). Moreover, in the night-time measurements, those parts of $\mathrm{LCZ}_{5}$ adjacent to $\mathrm{LCZ} 2$ were apparently warmer, while parts adjacent to LCZ D or B were apparently cooler. This was in return true for LCZ
$\mathrm{D}$ and $\mathrm{B}$, where the major factor of higher temperatures was the proximity of LCZ 2 or 5 and of lower temperatures the proximity of a watercourse. A large variance of temperature was detected during most measurements in LCZ 8, where one of the two included areas belonged to the warmest parts along the whole route thanks to the absence of pervious surfaces or greenery, while the other area was cooler thank to its proximity to a river. In case of LCZ 6 (open low-rise) the temperature variability was namely determined by the position outside or inside of the green belt (LCZ B) encircling the historical city centre ( $\mathrm{LCZ}_{2}$ ).

\section{Discussion}

The results of mobile measurements of air temperature using a bicycle in the city centre of Olomouc confirmed the highest air temperatures in the evening hours in the historical city centre with compact midrise buildings and a high percentage of impervious surfaces. The temperature maximum was expected in this area based on previous mobile measurements in adjacent areas accessible by car (Lehnert et al., 2018). It was also confirmed that the shape of the urban heat island of the city centre was modified by the prevailing wind direction in relation to the cooler areas near the city centre. Cooler spots developed in larger areas of scattered urban greenery with low share of impervious surfaces. In the noon hours, the highest temperatures were detected in the non-shaded areas with high proportion of impervious surfaces (adjacent shopping and industrial areas, squares in the city centre, and well irradiated streets). The lowest temperatures were regularly detected in the park area with a watercourse.

Assessing the influence of blue and green infrastructure on air temperature requires further research (Bowler et al., 2010; Broadbent et al., 2018). Therefore, in our follow-up research we will focus on detailed measurements in the surroundings of individual elements of blue and green infrastructure in the city centre.
Regarding the abovementioned factors affecting the temperature field in the city centre (orientation of the street canyons and influence of adjacent green areas), a relatively small study area, and the universal nature of the LCZ concept, we presumed that the LCZ concept may not be representative for such a small area. Nevertheless, the results show that temperature differentiation was apparent and often statistically significant even at this scale. During daytime, the highest temperatures were detected in LCZ E (bare rock or paved) and LCZ 8 (large low-rise). This is an important finding, as the air temperature is rarely measured in those zones and our results confirm the assumption about the location of the highest daily air temperatures into these zones within Central European cities based on the studies of land surface temperature (Geletič et al., 2016a) and model outputs (Geletič et al., 2016b, 2018).

During the night-time measurements, larger temperature differences were detected between the LCZs than during daytime. This is in accordance with the theoretical assumptions and the results of previous research studies (e.g. Lehnert et al., 2015; Skarbit et al., 2017; Savić et al., 2018). As expected, the highest temperatures were detected in LCZ 2 (compact midrise), which together with $\mathrm{LCZ}_{3}$ (not represented in 

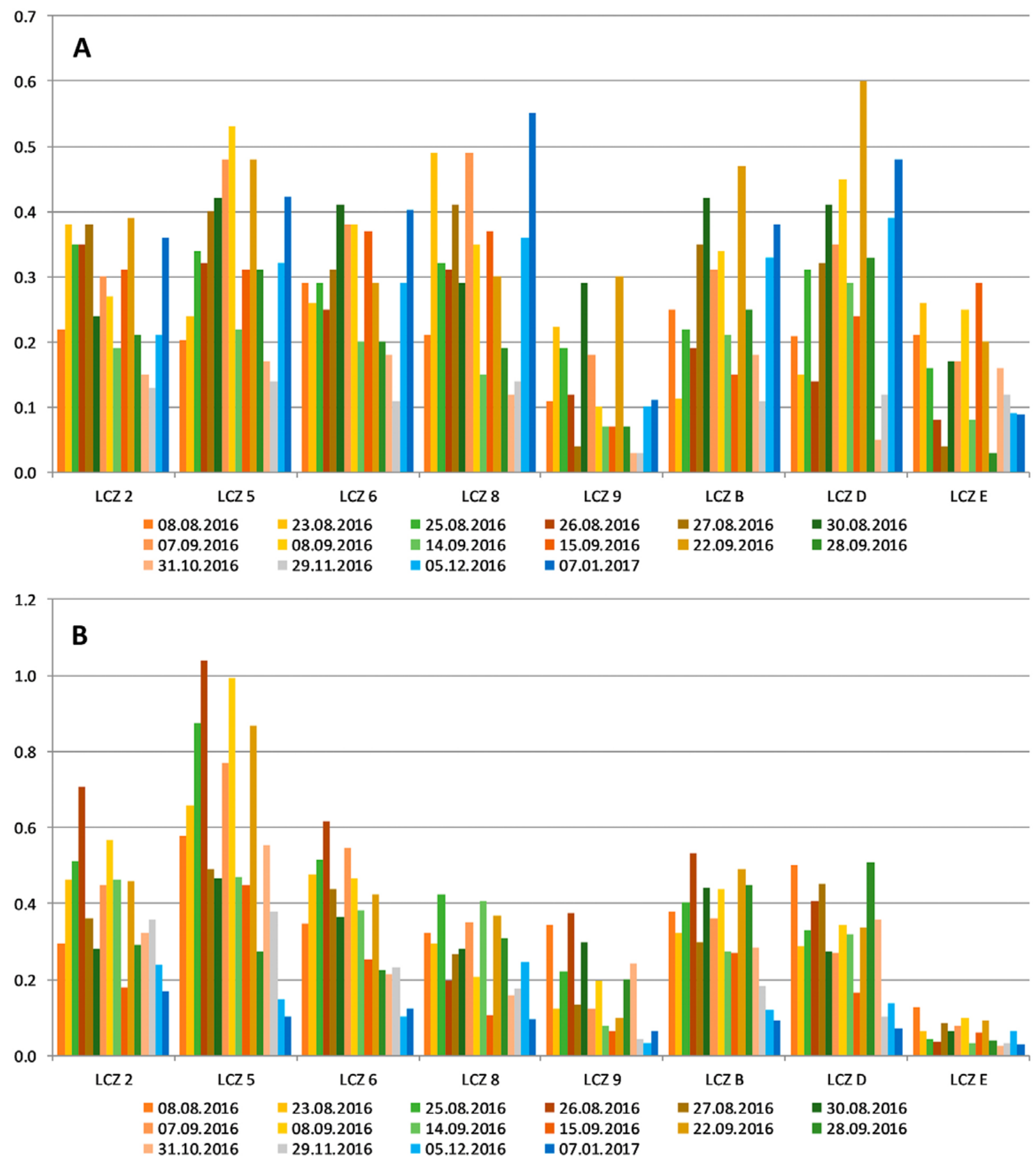

Figure 4. Standard deviation of air temperature within individual LCZs during (A) daytime measurements; (B) night-time measurements

Olomouc) belong to the warmest in the evening and night hours (see also Lelovics et al., 2014; Lehnert et al., 2018; Savić et al., 2018). The temperature differences between LCZs were generally higher in the summer than in the winter; lower temperatures in LCZs with higher share of vegetation were more pronounced in the vegetation season. The temperature differences were also influenced by weather conditions. For more robust studies in terms of the influence of seasonality and synoptic types onto the temperature differentia- tion of LCZs in (Central European) cities it is suitable to use networks of fixed site meteorological stations (e.g. Savić \& Milošević, 2018; Beck et al., 2018).

Considering the susceptibility of areas to the occurrence of hotspots, LCZ 2 (compact mid-rise) are predisposed to hotspot occurrence in the evening hours, while LCZ E (bare rock or paved) and LCZ 8 (large low-rise) are predisposed to hotspot occurrence in the daytime. Open spaces classified within LCZ 2 (e.g. squares) are also prone to hotspots occurrence in 
the daytime. Therefore, LCZs 2, 8 and E are considered most problematic in terms of heat stress affecting the population. We will aim for a precise identification of areas vulnerable to heat stress in selected LCZs in our follow-up research by measuring addi- tional characteristics influencing the perceived temperature. Therefore, we consider important the development of more sophisticated methods of mobile measurements by means of small, well equipped vehicles (see e.g. Queck \& Goldberg, 2018).

\section{Conclusion}

Mobile measurements using a bicycle provided detailed information on spatial differentiation of the field of temperature in the city centre and adjacent park areas, where mobile measurements using a car were not feasible. The measurements contributed to a more precise identification of areas prone to heat stress and pointed out to the necessity of a detailed research into the influence of individual elements of blue and green infrastructure on air temperature. Although the relatively small study area of the city cen- tre and its close surroundings was influenced by factors of microclimate, namely by the orientation of buildings affecting air temperature, the temperature differences between LCZs were in many cases statistically significant. It is possible to conclude that the characteristics contained in the definition of LCZs are a good representation of the factors forming local climate in the city. In LCZs identified as prone to occurrence of hotspots (LCZ 8, E and 2), further research into thermal comfort will be carried out.

\section{Acknowledgement}

This contribution was prepared within the project Identification of locations vulnerable to thermal stress - a tool for sustainable urban planning. Grant no. TJo10oo118 of the Technology Agency of the Czech Republic.

\section{References}

Alexander, P., \& Mills, G. (2014). Local Climate Classification and Dublin's Urban Heat Island. Atmosphere, 5(4), 755-774. doi:10.339o/atmos5040755

Beck, C., Straub, A., Breitner, S., Cyrys, J., Philipp, A., Rathmann, J., . . . Jacobeit, J. (2018). Air temperature characteristics of local climate zones in the Augsburg urban area (Bavaria, southern Germany) under varying synoptic conditions. Urban Climate, 25, 152-166. doi:10.1016/j.uclim.2018.04.007

Bowler, D.E., Buyung-Ali, L., Knight, T.M., \& Pullin, A.S. (2010). Urban greening to cool towns and cities: A systematic review of the empirical evidence. Landscape and Urban Planning, 97(3), 147155. doi:10.1016/j.landurbplan.2010.05.006

Broadbent, A.M., Coutts, A.M., Tapper, N.J., Demuzere, M., \& Beringer, J. (2018). The microscale cooling effects of water sensitive urban design and irrigation in a suburban environment. Theoretical and Applied Climatology, 134(1-2), 1-23. doi:10.1007/ s00704-017-2241-3

Buttstädt, M., Sachsen, T., Ketzler, G., Merbitz, H., \& Schneider, C. (2011). A new approach for highly resolved air temperature measurements in urban areas. Atmospheric Measurement Techniques Discussions, 4(1), 1001-1019. doi:10.5194/amtd-4-1001-2011
Cai, M., Ren, C., Xu, Y., Lau, K.K., \& Wang, R. (2018). Investigating the relationship between local climate zone and land surface temperature using an improved WUDAPT methodology - A case study of Yangtze River Delta, China. Urban Climate, 24, 485-502. doi:10.1016/j.uclim.2017.05.010

CZSO. (2018). Veřejná databáze, Vše o území: Olomouc (okres Olomouc), vybrané údaje za obec. Prague: Czech Statistical Office. (Available at: https://vdb.czso.cz/, 15.11.2018).

Dobrovolný, P., Řezníčková, L., Brázdil, R., Krahula, L., Zahradníček, P., Hradil, M., . . . Kolejka, J. (2012). Klima Brna: Víceúrovňová analýza městského klimatu. Brno: Masarykova univerzita.

Dobrovolný, P., \& Krahula, L. (2015). The spatial variability of air temperature and nocturnal urban heat island intensity in the city of Brno, Czech Republic. Moravian Geographical Reports, 23(3), 8-16. doi:10.1515/mgr-2015-0013

Fenner, D., Meier, F., Scherer, D., \& Polze, A. (2014). Spatial and temporal air temperature variability in Berlin, Germany, during the years 20012010. Urban Climate, 10, 308-331. doi:10.1016/j. uclim.2014.02.004

Gál, T., Skarbit, N., \& Unger, J. (2016). Urban heat island patterns and their dynamics based on an ur- 
ban climate measurement network. Hungarian Geographical Bulletin, 65(2), 105-116. doi:10.15201/ hungeobull.65.2.2

Geletič, J., \& Lehnert, M. (2016). GIS-based delineation of local climate zones: The case of mediumsized Central European cities. Moravian Geographical Reports, 24(3), 2-12. doi:10.1515/mgr-2016-0012

Geletič, J., Lehnert, M., \& Dobrovolný, P. (2016a). Land Surface Temperature Differences within Local Climate Zones, Based on Two Central European Cities. Remote Sensing, 8(10), 788. doi:10.339o/rs8100788

Geletič, J., Lehnert, M., \& Dobrovolný, P. (2016b). Modelled spatio-temporal variability of air temperature in an urban climate and its validation: a case study of Brno, Czech Republic. Hungarian $\mathrm{Ge}$ ographical Bulletin, 65(2), 169-180. doi:10.15201/hungeobull.65.2.7

Geletič, J., Lehnert, M., Savić, S., \& Milošević, D. (2018). Modelled spatiotemporal variability of outdoor thermal comfort in local climate zones of the city of Brno, Czech Republic. Science of The Total Environment, 624, 385-395. doi:10.1016/j.scitotenv.2017.12.076

IPCC. (2014). Part A: Global and Sectoral Aspects. Contribution of Working Group II to the Fifth Assessment Report of the Intergovernmental Panel on Climate Change. In Climate Change 2014: Impacts, Adaptation, and Vulnerability. CambridgeNew York: Cambridge University Press.

Leconte, F., Bouyer, J., Claverie, R., \& Pétrissans, M. (2015). Using Local Climate Zone scheme for UHI assessment: Evaluation of the method using mobile measurements. Building and Environment, 83, 3949. doi:10.1016/j.buildenv.2014.05.005

Lehnert, M., Geletič, J., Husák, J., \& Vysoudil, M. (2015). Urban field classification by "local climate zones" in a medium-sized Central European city: the case of Olomouc (Czech Republic). Theoretical and Applied Climatology, 122(3-4), 531-541. doi:10.1007/s00704-014-1309-6

Lehnert, M., Geletič, J., Dobrovolný, P., \& Jurek, M. (2018). Temperature differences among local climate zones established by mobile measurements in two central European cities. Climate Research, 75(1), 53-64. doi:10.3354/cro1508

Lelovics, E., Unger, J., Gál, T., \& Gál, C. (2014). Design of an urban monitoring network based on Local Climate Zone mapping and temperature pattern modelling. Climate Research, 60(1), 51-62. doi:10.3354/cro1220

Liu, Y., Peng, J., \& Wang, Y. (2017). Diversification of Land Surface Temperature Change under Urban Landscape Renewal: A Case Study in the Main City of Shenzhen, China. Remote Sensing, 9(9), 919. doi:10.3390/rs9090919
Melhuish, E., \& Pedder, M. (1998). Observing an urban heat island by bicycle. Weather, 53(4), 121-128. doi:10.1002/j.1477-8696.1998.tbo3974.x

Müller, N., Kuttler, W., \& Barlag, A. (2014). Counteracting urban climate change: adaptation measures and their effect on thermal comfort. Theoretical and Applied Climatology, 115(1-2), 243-257. doi:10.1007/s00704-013-0890-4

Mutani, G., \& Fiermonte, F. (2016). Microclimate models for a sustainable and liveable urban planning. In R. Ingaramo \& A. Voghera (Eds.), Topics and methods for urban and landscape design: From the river to the project, Urban and Landscape Perspectives. (pp. 183-209). Cham: Springer Nature. doi:10.1007/978-3-319-51535-9_11

Quanz, J.A., Ulrich, S., Fenner, D., Holtmann, A., \& Eimermacher, J. (2018). Micro-Scale Variability of Air Temperature within a Local Climate Zone in Berlin, Germany, during Summer. Climate, 6(1), 5. doi:10.339o/cli6010005

Queck, R., \& Goldberg, V. (2018). Cumulative Exposition of Pedestrians and Bikers in an Urban Environment. In 1oth International Conference on Urban Climate/14th Symposium on the Urban Environment (6-10 August 2018, New York).

Quitt, E. (1956). Př́spěvek k metodice výzkumu teplotních poměrů měst / Contribution to the methodology of research of temperature characteristics of towns. Meteorologické zprávy, 9(3), 69-74.

Rajkovich, N., \& Larsen, L. (2016). A Bicycle-Based Field Measurement System for the Study of Thermal Exposure in Cuyahoga County, Ohio, USA. International Journal of Environmental Research and Public Health, 13(2), 159. doi:10.339o/ijerph13020159

Savić, S., Lužanin, Z., Milosević, D., Kresoja, M. (2018). Intra-urban analysysi of air temperature in central-european city. The 1oth International Conference on Urban Climate (ICUC10) with the 14th Symposium on the Urban Environment (SUE) At: New York, USA

Skarbit, N., Gal, T., \& Unger, J. (2015). Airborne surface temperature differences of the different Local Climate Zones in the urban area of a medium sized city. In 2015 Joint Urban Remote Sensing Event (JURSE). (pp. 1-4). Institute of Electrical and Electronics Engineers (IEEE). doi:10.1109/jurse.2015.7120497

Skarbit, N., Stewart, I.D., Unger, J., \& Gál, T. (2017). Employing an urban meteorological network to monitor air temperature conditions in the local climate zones' of Szeged, Hungary. International Journal of Climatology, 37, 582-596. doi:10.1002/joc.5023

Stewart, I.D. (2011). A systematic review and scientific critique of methodology in modern urban heat island literature. International Journal of Climatolo$g y, 31(2)$, 200-217. doi:10.1002/joc.2141 
Stewart, I.D., \& Oke, T.R. (2012). Local Climate Zones for Urban Temperature Studies. Bulletin of the American Meteorological Society, 93(12), 1879-1900. doi:10.1175/bams-d-11-0oo19.1

Stewart, I.D., Oke, T.R., \& Krayenhoff, E.S. (2014). Evaluation of the 'local climate zone' scheme using temperature observations and model simulations. International Journal of Climatology, 34(4), 1062-1080. doi:10.1002/joc.3746

Tolasz, R. (2007). Atlas podnebí Česka - Climate atlas of Czechia. Olomouc: Český hydrometeorologický ústav; Prague: Univerzita Palackého v Olomouci.
Tsin, P.K., Knudby, A., Krayenhoff, E.S., Ho, H.C., Brauer, M., \& Henderson, S.B. (2016). Microscale mobile monitoring of urban air temperature. Urban Climate, 18, 58-72. doi:10.1016/j.uclim.2016.10.001

Wang, C., Middel, A., Myint, S.W., Kaplan, S., Brazel, A.J., \& Lukasczyk, J. (2018). Assessing local climate zones in arid cities: The case of Phoenix, Arizona and Las Vegas, Nevada. ISPRS Journal of Photogrammetry and Remote Sensing, 141, 59-71. doi:10.1016/j.isprsjprs.2018.04.009 